\title{
Scientific travel in the Atlantic world: the French expedition to Gorée and the Antilles, 1681-1683
}

\author{
NICHOLAS DEW*
}

\begin{abstract}
Although historians have long recognized the importance of long-range scientific expeditions in both the practice and culture of eighteenth- and nineteenth-century science, it is less well understood how this form of scientific organization emerged and became established in the seventeenth and early eighteenth centuries. In the late seventeenth century new European scientific institutions tried to make use of globalized trade networks for their own ends, but to do so proved difficult. This paper offers a case history of one such expedition, the voyage sponsored by the French Académie royale des sciences to Gorée (in modern Senegal) and the Caribbean islands of Guadeloupe and Martinique in 1681-3. The voyage of Varin, Deshayes and de Glos reveals how the process of travel itself caused problems for instruments and observers alike.
\end{abstract}

\section{Before expeditions}

From Bacon on, seventeenth-century thinkers often noted the links between the advancement of learning and the expansion of commerce. Yet until recently historians kept these two histories apart. Research of the last few years, however, has uncovered the range of connections between early modern colonial trade and the making of natural knowledge. ${ }^{1}$ The increasingly global circulation of scientific practices, itself

\footnotetext{
McGill University, Department of History, 855 rue Sherbrooke ouest, Montréal, Québec, H3A 2T7, Canada. Email: nicholas.dew@mcgill.ca.

My thanks to James Delbourgo, Florence Hsia, Jordan Kellman, Kapil Raj, François Regourd, Simon Schaffer, Margaret Schotte and Mary Terrall, as well as the anonymous referees, for their valuable comments on this piece.

1 See, among others, S. J. Harris, 'Long-distance corporations, big sciences and the geography of knowledge', Configurations (1998), 6, 269-304; J. E. McClellan III and F. Regourd, 'The colonial machine: French science and colonization in the ancien régime', Osiris (2000), n.s., 15, 31-50; P. H. Smith and P. Findlen (eds.), Merchants and Marvels: Commerce, Science and Art in Early Modern Europe, New York, 2002; S. Schaffer, 'Golden means: assay instruments and the geography of precision in the Guinea trade', in Instruments, Travel and Science: Itineraries of Precision from the Seventeenth to the Twentieth Century (ed. M.-N. Bourguet, C. Licoppe and H. O. Sibum), London, 2002, 20-50; L. Schiebinger and C. Swan (eds.), Colonial Botany: Science, Commerce, and Politics in the Early Modern World, Philadelphia, 2004; L. Schiebinger, Plants and Empire: Colonial Bioprospecting in the Atlantic World, Cambridge, MA, 2004; C. de Castelnau-L'Estoile and F. Regourd (eds.), Connaissances et pouvoirs: les espaces impériaux (XVIe-XVIIIe siècles): France, Espagne, Portugal, Pessac, 2005; K. Raj, Relocating Modern Science: Circulation and the Construction of Knowledge in South Asia and Europe, Delhi, 2006; J. Cañizares-Esguerra, Nature, Empire, and Nation: Explorations of the History of Science in the Iberian World, Stanford, 2006; H. J. Cook, Matters of Exchange: Commerce, Medicine, and Science in the Dutch Golden Age, New Haven, 2007; J. Delbourgo and N. Dew (eds.), Science and Empire in the Atlantic World, New York, 2008; D. Bleichmar et al. (eds.), Science in the Spanish and Portuguese Empires, 1500-1800, Stanford, 2008.
} 
made possible by commercial shipping, was crucial to the development of a wide range of disciplines from natural history to astronomy. Sociologists have argued that a distinguishing characteristic of the modern natural sciences is not so much their 'universality' as their reliance on networks and standards that are durable, stable and of global reach. ${ }^{2}$ A question that remains underexplored, however, is how those networks were created and how they functioned in the period that corresponds both with the transformation of science and with the globalization of European commerce.

Scientific travel has often been exemplified in the historical literature by the voyages of the late eighteenth century and the early nineteenth: the period from Cook to Darwin, by way of La Pérouse and Humboldt. These 'heroic' examples have become so canonic, in fact, that analyses of other scientific journeys often rely on them as reference points. ${ }^{3}$ The celebrated expeditions of the later eighteenth century and the early nineteenth may not, however, offer the best models for understanding scientific travel in earlier, or indeed later, periods. Prior to the 1730s the 'scientific expedition' as a way of doing scientific work had not yet achieved a stable form and had yet to acquire the cultural prestige it later gained. So in an important sense there was no such thing as a 'scientific expedition' in this period. Yet this is an essay about one. As early as the 1670 s the newly established scientific academies of Europe sought to employ long-range trade networks for the benefit of astronomy, cartography and natural history. The Académie royale des sciences in Paris was one of the most active in this enterprise. Between 1670 and 1700 it sent observers to Acadia and Cayenne, to West Africa and the Caribbean, to Brazil and the Far East. ${ }^{4}$ But it was by no means self-evident how the new scientific institutions might interact with the trading companies. The academies' attempts to employ pre-existing trade networks for scientific ends were by no means guaranteed success.

How scientific practice was trafficked around the baroque Atlantic world, an economy shaped to a large extent by the slave trade, can be explored through a detailed account of one scientific voyage, the Académie's expedition to West Africa and the

2 See, for example, B. Latour, Science in Action: How to Follow Scientists and Engineers through Society, Milton Keynes, 1987, 247-57; see also D. N. Livingstone, Putting Science in Its Place: Geographies of Scientific Knowledge, Chicago, 2003, esp. 135-78.

3 On the eighteenth-century expeditions see K. Raj, 'Eighteenth-century Pacific voyages of discovery, “Big Science", and the shaping of a European scientific and technological culture', History and Technology (2001), 17, 79-98; D. P. Miller and P. H. Reill (eds.), Visions of Empire: Voyages, Botany, and Representations of Nature, Cambridge, 1996; R. Sorrenson, 'The ship as a scientific instrument in the eighteenth century', Osiris (1996), 11, 221-36; R. Iliffe, 'Science and voyages of discovery', in The Cambridge History of Science, vol. 4 : Eighteenth-Century Science (ed. R. Porter), Cambridge, 2003, 618-45. On canonization see M. Terrall, 'Heroic narratives of quest and discovery', Configurations (1998), 6, 223-42.

4 See J. W. Olmsted, 'The scientific expedition of Jean Richer to Cayenne (1672-1673)', Isis (1942), 34, 117-28; idem, 'The voyage of Jean Richer to Acadia in 1670', Proceedings of the American Philosophical Society (1960), 104, 612-34; F. C. Hsia, 'Jesuits, Jupiter's satellites, and the Académie royale des sciences', in The Jesuits: Cultures, Sciences and the Arts, 1540-1773 (ed. J. W. O’Malley et al.), Toronto, 1999, 241-57; idem, Sojourners in a Strange Land: Jesuits and Their Scientific Missions in Late Imperial China, Chicago, forthcoming; J. Kellman, 'Discovery and enlightenment at sea: maritime exploration and observation in the eighteenth-century French scientific community’, Princeton University Ph.D. dissertation, no. AAT 9813872, 1997; F. Regourd, 'Sciences et colonisation sous l'ancien régime: le cas de la Guyane et des Antilles françaises, XVIIe-XVIIIe siècles', doctoral thesis, Université de Bordeaux-III, 2000, esp. 233-358. 
Caribbean of 1681-3. Three envoys of the Académie - Jean Deshayes, Guillaume de Glos and someone we know only as Varin - travelled to Gorée, the fortified island off the coast of Senegambia (near modern Dakar), then to the French colonies of Guadeloupe and Martinique in the Caribbean. Deshayes and Varin travelled together first. De Glos went out on a different ship and joined them at Gorée. On their return to Paris the following year their observations were written up and eventually published by the Académie. ${ }^{5}$ The mission had been conceived as part of the Académie's global mapping project and the envoys' tasks were therefore primarily astronomical. However, the mission became known for its figure for the length of a seconds pendulum at Goree, which was cited and debated by Newton in the Principia in connection with the shape of the Earth.

This case brings to light how difficult it was in this period for a scientific institution to carry out a long-range expedition at all. Using commercial vessels meant that control was distributed: ship captains were loath to take astronomers aboard, and the routes and destinations of the voyage were out of the Académie's hands. The Académie was not alone in this, since even royal ministers had difficulty maintaining control and communication across the Atlantic. ${ }^{6}$ The Atlantic trade network was far from stable in this period. At the same time, because only two or three envoys were sent out, their success depended on how well they worked together and coped with the demands of the journey itself.

\section{Cassini's maps, Huygens's clocks}

The voyage of Varin, Deshayes and de Glos was first planned as a trip to the Canary Islands. In 1680 the Académie was pleased with the success of its missions to establish the latitude and longitude of Bayonne and Brest at the south-western and western extremities of France. Longitude was measured on land by the simultaneous observation of the eclipses of Jupiter's moons. Academicians wrote of Cassini's grand dessein to map France and the world with new precision by gradually accumulating coordinates and plotting them on a floor-map in the western tower of the Paris Observatoire. ${ }^{7}$ In February 1681 the academician Jean Picard presented Colbert with a

5 G.-D. Cassini (I), Les Elemens de l'astronomie verifiez par Monsieur Cassini par le rapport de ses tables aux observations de M. Richer faites en l'isle de Cä̈enne: avec les observations de MM. Varin, Des Hayes, et De Glos faites en Afrique \& en Amerique, Paris, '1684', 51-74, part 5 of [Académie des sciences], Recueil d'observations faites en plusieurs voyages par ordre de Sa Majesté, pour perfectionner l'astronomie et la géographie, Paris, 1693. Although printed in 1684, the fascicule was not widely available until the Recueil was published in 1693. See H. Oldenburg, Correspondence (ed. A. R. Hall and M. Boas Hall), 13 vols., Madison, 1965-86, xiii, 198, n. 5; and C. Huygens, Oeuvres complètes (ed. D. Bierens de Haan and J. Bosscha), 22 vols., The Hague, 1888-1950, ix, 114 (La Hire to Huygens, 5 December 1686). The account was reprinted as 'Observations astronomiques faites au Cap Verd, en Afrique, et aux Isles de l'Amérique', in Mémoires de l'Académie Royale des Sciences: depuis 1666 jusqu'à 1699, Paris, 1729, vii, 431-59.

6 I. K. Steele, The English Atlantic, 1675-1740: An Exploration of Communication and Community, New York, 1986; and K. J. Banks, Chasing Empire across the Sea: Communications and the State in the French Atlantic, 1713-1763, Montreal and Kingston, 2002.

7 Archives de l'Académie des Sciences (Paris), Registres des Procès-Verbaux (henceforth AAS, RPV), 9, ff. 89r-92v, 'L'Inuention des Longitudes verifiee par les Observations nouuelles', read by Cassini at session of 
project to map the whole of France. ${ }^{8}$ What the reform of cartography still lacked, though, was a seemingly essential foundation: an agreed zero-line for longitude. By ancient tradition the first meridian was placed at the Fortunate Isles, the western limit of the ancient world, but there was no agreement on which islands the Fortunate Isles were. As pilots' manuals frequently complained, various first meridians were in use, including points in the Azores, the Canaries and even the Cape Verde islands. ${ }^{9}$ In the late seventeenth century, geographers still cherished the ideal of using the Fortunate Isles, though in practice Greenwich and Paris would become de facto authorities during the next few decades. The Académie's commitment to the idea in the 1680 s might seem puzzling were it not for a 1634 ordonnance, still in force, which ordered French cartographers and pilots to set their first meridian through the westernmost of the Canary Islands, Hierro (or 'l'île de fer'). ${ }^{10}$ However, the decision to fix the first meridian at Hierro was made without a precise figure for its longitude in relation to Paris; hence the Académie's decision to send observers to the Canaries. ${ }^{11}$

Excitement about the mapping project reached new heights in December 1681. Cassini had explained it to Louis XIV, who came to visit the Académie a few days later. ${ }^{12}$ Philippe de La Hire wrote to Christiaan Huygens, then living in Holland, about the Canaries mission and noted the king's visit. Huygens agreed that the new expedition was a clear sign of royal support but wanted to know who was being sent. ${ }^{13}$ However useful the voyage might be in principle, its success would depend on the skills of the envoys. Huygens was very sensitive to this issue. In the late 1660 s, clocks he had

14 December 1680. On Cassini's method see A. Van Helden, 'Longitude and the satellites of Jupiter', in The Quest for Longitude (ed. W. J. H. Andrewes), Cambridge, MA, 1996, 86-100. On the mapping project see L. Gallois, 'L'Académie des sciences et les origines de la Carte de Cassini', Annales de géographie (1909), 18, 193-204, 89-310; J. W. Konvitz, Cartography in France, 1660-1848: Science, Engineering, and Statecraft, Chicago, 1987, 1-8; and L. A. Brown, Jean Domenique [sic] Cassini and His World Map of 1696, Ann Arbor, 1941, which contains a translation of the published set of Cassini's instructions at 47-60.

8 AAS, RPV, 9, ff. 96v-97r. Picard's proposal for a triangulation survey was not seen through until the end of the ancien régime: see J.-P. Martin, Une Histoire de la méridienne: Textes, enjeux, débats et passions autour du méridien de Paris, 1666-1827, Cherbourg, 2000.

9 See, for example, G. de Glos, Le Manuel des pilotes, ou l'introduction à la navigation, contenant les principes de cet art, Rouen, 1678, 39-40; cf. J. Le Rond d'Alembert, 'Méridien', in Encyclopédie, ou dictionnaire raisonné des sciences, des arts et des métiers (ed. D. Diderot and d'Alembert), 35 vols., Paris, 1751-80, x, 383-4.

10 L. Lagarde, 'Historique du problème du méridien origine en France', Revue d'histoire des sciences (1979), 32, 289-304. See also G. Bigourdan, 'La Conférence des longitudes de 1634: la déclaration de Louis XIII relative au premier méridien', Comptes rendus de l'Académie des sciences (1916), 163, 229-33, 319-23.

11 The Hierro scheme is first mentioned, along with Varin's name, in a report of the Académie's mathematics section for August 1680-15 June 1681: AAS, RPV, 9 bis, f. 107 r-v.

12 AAS, RPV, 9 bis, f. 123v (29 November 1681): ' Mr Cassini a fait son rapport de ce que le Roy luy auoit fait l'honneur de luy dire touchant le dessein qu'on a d'obseruer les longitudes'; the royal visit was the following Friday (5 December 1681).

13 Huygens to La Hire, 19 February 1682 ('Je me rejouis de voir que le Roy et Monseign[eur] Colbert prennent son avancement encore plus à cour, que par le passé, dont ces voiages бoc. sont d'indisputables marques ... Mais je souhaiterois bien d'estre informé touchant les personnes qui ont esté choisies pour aller faire ces observations eloignees'): Huygens, op. cit., (5), iii, 344; replying to La Hire to Huygens, 31 January 1682, iii, 339. 
designed were tested at sea. Huygens had persistently blamed the technicians in charge of the clocks (La Voye-Mignot and Richer) for the trials' unsuccessful outcome. ${ }^{14}$

Huygens was hardly alone in his awareness of how difficult it was to make observational technique travel, especially on the high seas. The Académie's envoys and their instruments were to be a travelling miniature observatory, provided with the minimum equipment to carry out their tasks. However, if this field observatory were to carry out those tasks usefully, its instruments and working practices needed to be carefully calibrated before departure. The observers' selection and training therefore formed a crucial part of the Académie's attempt to control its agents. Unfortunately, we have little evidence of the institutional backgrounds of Varin, Deshayes or de Glos, nor of how they came into contact with the Académie. The Académie recruited for other missions either from the royal corps of military engineers (ingénieurs $d u$ roi) or the recently established hydrography schools. The status of such recruits in their relations with the Académie was not formalized in this period, but they were clearly subordinate to the full members of the Académie. It is certain, too, that Varin, Deshayes and de Glos were never fully fledged members of the Académie. ${ }^{15}$ Varin, it seems, had been a teacher of mathematics in Paris. ${ }^{16}$ He was proposed for the voyage by some of the academicians. Jean Deshayes may (or may not) be the same Deshayes who was involved in testing a longitude scheme for the Académie in the late 1660s. ${ }^{17}$

Varin and Deshayes were trained by Cassini at the Observatoire for several months before they left. Guillaume de Glos had been a hydrography teacher at Honfleur (in Normandy), and had written to Cassini to ask whether he could be of use in the Académie's expeditions. ${ }^{18}$ Cassini obliged by drawing up a new mission, in which de Glos and two assistants were to join Varin and Deshayes at the Canaries and proceed with them to the island of São Tomé, the Portuguese slave-trading post in the Gulf of Guinea where they were to stay several months making solar observations almost at the

14 Olmsted, 'Scientific expedition of Jean Richer to Cayenne', op. cit. (4), 120; idem, 'Voyage of Jean Richer to Acadia', op. cit. (4), 618, 632-3; and M. S. Mahoney, 'Christiaan Huygens, the measurement of time and longitude at sea', in Studies on Christiaan Huygens (ed. H. J. M. Bos et al.), Lisse, 1980, 234-70.

15 Some of those sent on other expeditions, such as Richer and La Voye-Mignot, had the status of élève ('trainee'), but this was not yet an official rank within the Académie. On preparations for this mission see A. Mallon, 'Science and government in France, 1661-1699: changing patterns of scientific research and development', Ph.D. thesis, Queen's University, Belfast, 1983, 121-5, 160-1. For hydrography teaching see F. Russo, 'L'Hydrographie en France aux XVIIe et XVIIIe siècles: Ecoles et ouvrages d'enseignement', in Enseignement et diffusion des sciences en France au XVIIIe siècle (ed. R. Taton), Paris, 1964, 419-40; and Kellman, op. cit. (4). C. Wolf, Histoire de l'Observatoire de Paris de sa fondation à 1793, Paris, 1902, 144-5, claims (144 n. 1) that Varin and Deshayes were ingénieurs du roi pour l'hydrographie, but gives no evidence for this.

16 In a letter to Varin and Deshayes, 7 November 1681, Cassini mentions that Varin had taught mathematics at the house of Pablo Spinola Doria, marquis of Los Balbases, whilst he was ambassador in Paris, in the late 1670s (Paris, Bibliothèque de l'Observatoire, hereafter Bib. Obs., D. 1. 11, bundle B).

17 Mallon, op. cit. (15), 121; cf. Olmsted, 'Voyage of Jean Richer to Acadia', op. cit. (4), 622-5. See also J. S. Pritchard, 'Deshayes, Jean', in Dictionary of Canadian Biography (ed. G. W. Brown), 14 vols., Toronto, 1965-91, s.v.

18 Bib. Obs. B. 4. 9 bis, bundle De Glos, letter dated 14 November 1681. On de Glos's earlier career see A. Anthiaume, Evolution et enseignement de la science nautique en France, et principalement chez les Normands, 2 vols., Paris, 1920, i, 217-9, 300-6. 
equator. Cassini therefore wrote to La Hire, then in Normandy, asking him to meet de Glos and give him some training 'in the method that we practice' ${ }^{19}$ Here and elsewhere Cassini implied that the Académie had its own method, best passed on by personal contact. There was something in this: after all, although the idea of finding longitude using Jupiter's moons was no secret, Cassini had made himself a specialist in observing the satellites and his latest figures were still unpublished. ${ }^{20}$

Cassini composed two sets of instructions for the envoys to be read to the Académie: a 'General Instruction for the geographical observations to be made in voyages' as well as 'Particular instructions' for the individual locations visited.$^{21}$ In the 'particular' instructions for the Canaries, Cassini told his envoys to map the islands, to survey the height of the Pico Tenerife and to climb it with a barometer, and to look out for a species of water-producing tree that was supposed to grow there. In contrast, the 'General Instruction' covered the set of routine observations that should be made in any place visited for long enough to set up the clocks and instruments. Since clocks were essential to almost all the observations, a large part of the envoys' daily routine centred on the upkeep of two pendulum clocks. Each morning and afternoon equal altitude observations (observations correspondantes) were to be taken from which the 'going' of the clocks in relation to mean solar time could be reckoned. ${ }^{22}$ The most useful observations were those simultaneously made in Paris and neither party had any way of knowing which celestial events would be seen by the other group. So the envoys had to maintain a strict rhythm of observation to produce a long enough series of results to maximize the number of simultaneous observations.

As a coda to the routine astronomical observations the agents were also to record other physical variables: the variation of the compass, the times of tides and daily barometer and thermometer readings. They were also to measure the length of a pendulum beating seconds. Since the early 1670s the Académie had been testing the seconds pendulum as a standard for length measurements. ${ }^{23}$ Thus far, measurements from Uraniborg down to Bayonne seemed to be invariant. The only outstanding divergent figure was that reported by Jean Richer at Cayenne in 1672. Richer had reported that a

19 Bib. Obs. A. 4. 2, bundle 36, 17, item Mm: Cassini to La Hire (copy of outgoing letter), 21 November 1681 ('pour s'exercer dans la méthode que nous pratiquons'), also cited by Wolf, op. cit. (15), 144 n. 1; cf. item Hh, Cassini to Picard, 22 November 1681 ('apprendre la méthode dont nous nous seruons'). La Hire had initially hoped to go to the Canaries himself, but had been too ill in the summer of 1681 (Mallon, op. cit. (15), 121).

20 Cassini had published a set of tables for Jupiter's satellites in 1668, but his revised tables were not published until 1693. See also Hsia, 'Jesuits, Jupiter's satellites', op. cit. (4); Van Helden, op. cit. (7), 96.

21 Cassini-I, 'Instruction générale pour les observations géographiques à faire dans les voyages': incomplete copy at Bib. Obs. D. 1. 11, bundle A1; complete copy at AAS, RPV, 9 bis, ff. 141r-147r, included in the published account of the voyage ('Observations astronomiques faites au Cap Verd', op. cit. (5), 432-8); 'Instruction particulière pour le voyage des Canaries', original at Bib. Obs. D. 1. 11, bundle A1; copy at AAS, RPV, 9 bis, ff. 135r-137r. 'Instruction pour les Observations qu'il faudra faire dans l'isle de St Thomé', copy at AAS, RPV, 9 bis, $\mathrm{ff} .150 \mathrm{v}-154 \mathrm{r}$.

22 On this 'equal altitude' technique see Andrewes, 'Finding local time at sea, and the instruments employed', in The Quest for Longitude (ed. W. J. H. Andrewes), 394-404, 396.

23 L. Defossez, Les Savants du XVIIe siècle et la mesure du temps, Lausanne, 1946, 153-67; P. Costabel, 'Picard et l'étalon universel de longueur fondé sur le pendule', in Jean Picard et les débuts de l'astronomie de précision au XVIIe siècle (ed. G. Picolet), Paris, 1987, 315-28. 
seconds pendulum in Cayenne was shorter than in Paris by one and a quarter twelfths of a Paris inch. This was a result that many of his superiors were willing to treat as an error. To resolve the doubt over Richer's finding, Cassini wanted Varin and Deshayes to take particular care over the pendulum experiment. ${ }^{24}$ These measurements were later to be taken up by Newton as evidence for his theory that the Earth is an oblate spheroid. ${ }^{25}$ However, the measures were to remain controversial for several decades. ${ }^{\mathbf{2}}$

With these tasks in view, Varin and Deshayes were equipped with tubes and lenses made by Jacques Borelly for an eighteen-foot telescope. ${ }^{27}$ They also carried a two-anda-half-foot quadrant that had been used by Jean Richer in Cayenne; two pendulum clocks, 'large' and 'small'; a barometer and a thermometer; a compass; and materials for the seconds pendulum experiment, presumably a brass ball, thread (the favoured material was pite, or 'silkgrass', a South American hemp) and an iron ruler. ${ }^{28}$ When he left de Glos took another eighteen-foot telescope, a pendulum clock and a three-foot sextant. ${ }^{29}$ They also travelled with the papers to which they needed to refer, including handwritten tables from Cassini (updated by post whenever possible) and at least one printed book, the Geographiae et Hydrographiae Reformatae by Cassini's old mentor, the Bologna Jesuit Giovanni Battista Riccioli. ${ }^{30}$

Before the departure from Paris the instruments were calibrated against instruments at the Observatoire. ${ }^{31}$ Cassini designed the envoys' working procedures to give him as much control as possible over their observations. He preferred them to send their data in as raw a state as possible and also reserved the right to decide the relevant margins of error. ${ }^{32}$ Both Varin and Deshayes were ordered to keep their own logbook of

24 Olmsted, 'Scientific expedition of Jean Richer to Cayenne', op. cit. (4). On the debates over Richer's finding see N. Dew, 'Vers la ligne: circulating measurements around the French Atlantic', in Delbourgo and Dew, op. cit. (1), 53-72.

25 I. Newton, The 'Principia': Mathematical Principles of Natural Philosophy, tr. I. B. Cohen and A. Whitman, Berkeley, 1999, 826-32 (Book 3, Proposition 20). Even in the first edition (1687), Newton refers to figures from Gorée, although without naming the observers. On Newton's handling of such data, see Schaffer, op. cit. (1), 37-8, and idem, The Information Order of Newton's Principia Mathematica, Uppsala, 2008.

26 M. Terrall, 'Representing the Earth's shape: the polemics surrounding Maupertuis's expedition to Lapland', Isis (1992), 83, 218-37; R. Iliffe, “"Aplatisseur du monde et de Cassini": Maupertuis, precision measurement and the shape of the Earth in the 1730s', History of Science (1993), 31, 335-75; J. L. Greenberg, The Problem of the Earth's Shape from Newton to Clairaut, Cambridge, 1995; N. Safier, Measuring the New World: Enlightenment Science and South America, Chicago, 2008.

27 AAS, RPV, 9 bis, f. 128v: 'Mr Borelli a donné des verres objectifs de 18 pieds pour faire ces obseruations.' Cassini and Huygens did not have a high opinion of Jacques Borelly's lenses. A. Stroup, A Company of Scientists: Botany, Patronage and Community at the Seventeenth-Century Parisian Royal Academy of Sciences, Berkeley, 1990, 20; Mallon, op. cit. (15), 104-5.

28 This is based on J. Picard, Mesure de la terre, Paris, 1671, 3-5.

29 According to Wolf, op. cit. (15), 144 n. 1, citing no sources.

30 G. B. Riccioli, Geographiae et Hydrographiae Reformatae libri duodecim, Bologna, 1661; reprinted Venice, 1672. Varin and Deshayes mention using it (e.g. Bib. Obs. B. 5. 2, p. 61).

31 This is reported in the published account: 'Observations astronomiques faites au Cap Verd', op. cit. (5), 439-41 ('On regla à la situation horisontale le quart de Cercle de deux pieds \&o demi, qui avoit été rapporté de Caïenne, ơ qu’on avoit divisé de nouveau à cause que la premiere division avoit été éffacée').

32 For example, Cassini to Varin and Deshayes, Paris, 7 March 1682 (copy), Bib. Obs. D. 1. 11, bundle B: Cassini has sent some tables for Jupiter's satellites ('les feuilles des configurations des satellites de Jupiter pour 
observations to act as a check on the other, and to make three copies of everything they recorded: one to retain, one to send back to France if a ship bound for Europe happened to pass, and another to leave with the local consul, presumably in case they died or lost their notes on the way home. ${ }^{33}$

Like other such documents, Cassini's instructions for travellers represent an observational utopia. ${ }^{34}$ Instruments could be calibrated, pupils trained, but once Varin and Deshayes left Paris, Cassini was working in the dark, his communication with them entirely dependent on the post. Securing a passage for the astronomers and their instruments was no simple matter and an itinerary planned in Paris meant little at the dockside.

\section{Negotiations with the Senegal Company}

Varin, Deshayes and de Glos were to reach neither Hierro nor São Tomé. To explain why requires an examination of the Académie's relations with the slave-trading company. In July 1681, after a brief day trip to Sceaux to meet Colbert, Varin and Deshayes left Paris for Rouen, where they were expecting to board a ship of the Compagnie du Sénégal. Always supportive of Cassini's work, Colbert himself made the diplomatic arrangements to allow the astronomers to visit the Spanish and Portuguese colonies. ${ }^{35}$ Having a passport, however, was not the same as having a passage. An opportunity to sail for the Canaries arose in summer 1681, just as the mission of Varin and Deshayes was being prepared, with the re-establishment of the French Senegal Company after a financial crisis. ${ }^{36}$ The person who seems to have created the link between the Académie and the new company was Cassini himself. As it happened, one of the directors of the new company was his old acquaintance, an adventurer named Dancourt, who had offered his services to Cassini. ${ }^{37}$ Not long after Varin and Deshayes had left, Dancourt prepared a voyage to Gorée and it was on his ship that Guillaume de Glos travelled.

trois autres mois que vous n'auez pas') and adds that he is deliberately neglecting certain inaccuracies ('Je dis a quelques minutes prez, parce qu'il y a des inegalitez que je neglige icy').

33 Cassini, 'Instruction particulière pour le voyage des Canaries'; 'Instruction générale'.

34 See M.-N. Bourguet and C. Licoppe, 'Voyages, mesures et instruments: Une nouvelle Expérience du monde au siècle des Lumières', Annales: histoire, sciences sociales (1997), 52, 1115-51, 1121.

35 Colbert told the French ambassador in Lisbon to ask the Portuguese crown to tell the governor of São Tomé to expect the expedition: J.-B. Colbert, Lettres, instructions et mémoires de Colbert (ed. P. Clément), 10 vols., Paris, 1861-82, v, 421-2, 17 February 1682. Later, Colbert paid de Glos expenses of 2,300 livres (ibid., 495; cf. Comptes des Bâtiments du Roi sous le règne de Louis XIV (ed. J.-J. Guiffrey), 5 vols., Paris, 1881-1901, ii, col. 236), but no record exists of a similar payment to Varin and Deshayes for this voyage.

36 On this crisis and its effects see G. Antonetti, 'Colbert et le crédit public', in Un nouveau Colbert (ed. R. Mousnier), Paris, 1985, 189-210, esp. 200-1. On the Senegal companies see A. Ly, La Compagnie du Sénégal, new edn., Dakar, 1993.

37 Cassini-I, 'Anecdotes de la Vie de J.-D. Cassini, rapportées par lui-même', in J.-D. Cassini (IV), ed., Mémoires pour servir à l'histoire des sciences et à celle de l'Observatoire Royal de Paris, suivis de la Vie de Jean Dominique Cassini écrite par lui-même, Paris, 1810, 291: 'M. Dancourt ... me vint trouver, et s'offrit de travailler sous ma direction aux opérations ... dans des pays éloignés, pour la détermination des longitudes. Ce fut lui qui, après quelques années, conduisit au Cap Vert et à l'ile de Gorée MM. Varin, Deshayes et de Glos.' In fact, only de Glos travelled with Dancourt. 
The island of Goree had been captured from the Dutch by the French vice-admiral Jean d'Estrees in the autumn of 1677 and was one of the company's key bases in Senegambia.

Despite the connection between Cassini and Dancourt, Varin and Deshayes still found it difficult to board the company's ships. They spent autumn 1681 trapped in a series of bureaucratic entanglements in Normandy ports. After several weeks in Rouen, where their ship was supposed to be, they were told that they should go to Dieppe instead. Deshayes asked Cassini to find out what was amiss and to make sure letters of recommendation were sent to Dieppe. ${ }^{38}$ On reaching Dieppe in early November they found that no orders had reached the company's local representatives. Back in Paris, Cassini visited the offices of the company in rue de Cléry, and was told that the orders to allow Varin and Deshayes to embark had been issued and that they should speak to a certain Dieppe merchant, Madame Baudry. ${ }^{39}$ As time passed it seemed to Deshayes that the company were trying to avoid having to take the two astronomers on board. The dispatches (dépêches) for the ship's departure did not arrive, then an agent of the company who was bringing the orders for their embarkation got mysteriously held up in Le Havre; meanwhile the captain of the ship was waiting for a suitable tide. ${ }^{40}$ Deshayes's suspicions were confirmed in early December, when (as he told Cassini) he 'spotted some passages' in a letter to one of the company's men, Soubret, 'ordering him not to take us to the Canaries, but to convince us of the reasons they have not to do so' ${ }^{41}$ It is not clear what the company's objections were, but it could be supposed that any delay in the Canaries was regarded as undesirable in what was intended to be a slave-trading voyage. Perhaps the inconvenience of housing the envoys and their rather bulky instruments on the ship was also a factor. ${ }^{42}$

During these wranglings, and as early as the beginning of November, it had become clear to Cassini that the voyage of Varin and Deshayes might become longer than expected. He was happy for them to visit Senegal, 'a place that certainly merits observation', although it may be that he still thought it would be possible to visit Hierro on the way. ${ }^{43}$ In a letter to Cassini of December 1681, Varin accepted this news with a

38 Deshayes to Cassini, Rouen, 23 October 1681, Bib. Obs. B. 4. 9 bis, bundle 'Deshayes'.

39 Cassini to Varin and Deshayes, Paris, 7 November 1681, Bib. Obs. D. 1. 11, bundle B (copy). Madame Baudry, 'marchande de Dieppe', is probably Marthe Baudry (c.1661-1743), business partner and future wife of the privateer-cum-colonial governor, Jean Du Casse. See Dictionnaire de biographie française, art. 'Du Casse, Jean'.

40 Deshayes to Cassini, Dieppe, 18 November 1681, Bibliothèque nationale de France (hereafter BN), ms n. a. fr. 6197 , ff. $87-8$.

41 Deshayes to Cassini, Dieppe, 10 December 1681, Bib. Obs. B. 4.9 bis, bundle 'Deshayes' ('j’ay entreueu quelques endroits d'une autre lettre où on luy mande non de nous mener aux Canaries mais de nous faire trouuer bon les raisons qu'ils ont de ne le pas faire').

42 Similar reluctance is documented in Olmsted, 'Voyage of Jean Richer to Acadia', op. cit. (4), 623.

43 Cassini to Varin and Deshayes, Paris, 7 November 1681, Bib. Obs. D. 1. 11, bundle B (copy): 'mais vous ne deuriez pas pour cela laisser de vous embarquer, quand mesme vous deuriez aller au Senega [sic], qui est vn lieu qui merite bien d'estre obserué, et cela en cas qu'il ny eut pas d'autre vaisseau qui fut prest de partir en cette saison'. 
certain amount of trepidation, protesting that 'were it not for my family' he would be happy to go as far as Japan, if Cassini ordered it. ${ }^{44}$

The ship that Varin and Deshayes were waiting for permission to board was Le Conquis (The Conquered), a 'prize' recently captured off the African coast from the Danish slave-trade company. ${ }^{45}$ It seems that the captain, Charles Layolle, or Laguyolle, also made an effort to dissuade the two astronomers from their mission. Varin records a conversation with the ship's captain:

We have spoken to Captain Layolle, who told us that he had received orders from M. Soubret to let us disembark at the Cap-Vert [Gorée]. But, [since he] told us that this country [is] very deserted of things necessary to life, and that we would have to live with the negroes [nègres], who live very badly, we offered to pay him some rent to live off his provisions. He replied that he could not do this, because as soon as he arrived in Senegal, he would do all he could to leave as soon as possible to go to the Isles of America [the Antilles], where he could not take us without an express order from the Company, so that if we want to sail to the Cap-Vert we have no choice but to go to the Isles as well, given that we can only get back to France aboard the same vessel. ${ }^{46}$

Varin went on to ask Cassini to help by sending orders that could in no way be evaded. Clearly, though, difficulties remained. Cassini made sure new orders were sent and even obtained orders from the governor of Gorée, Jamineau, which finally proved sufficient for Captain Layolle. ${ }^{47}$

With all these delays, Varin and Deshayes had plenty of time to determine the longitude and latitude of Dieppe. Deshayes also passed time discussing the peculiarities of the harbour's tides with a local watch-owning virtuoso and a group of sailors. ${ }^{48}$ However, even after the administrative problem was solved, the ship had to wait for the

44 Varin to Cassini, Dieppe, 11 December 1681, BN ms n. a. fr. 6197, ff. 170-1, f. 170r: 'Puis que Vous souhaittez que lon aille au Cap Vert Je seray bien aise de faire ce Voyage et il me suffit de scauoir que Vous le souhaittez pour me faire trouner du plaisir a lentreprendre et Je puis Vous protester que si je nestois point en famille jirois jusqu'au Japon si vous me lordonniez pour auoir la gloire destre du nombre de ceux qui executeront vos illustres projets dans toutes les parties du monde.'

45 Some of the voyage's details are recorded by another of Le Conquis's passengers, one François de Paris: G. Thilmans, 'La Relation de François de Paris (1682-1683)', Bulletin de l'Institut fondamental d'Afrique noire, series B (1976), 38/1, 1-51.

46 Varin to Cassini, Dieppe, 11 December 1681, BN ms n. a. fr. 6197, ff. 170-1, f. 171r: 'Nous auons parlé a Mr le Capitaine Layolle qui nous a tesmoigné qu'il auoit ordre de Mr So[u]bret de nous debarquer au Cap Vert. Mais nous ayant témoigné que ce pays estant tres desert des choses necessaires a la Vie, et que nous ne pounions viure qu'auec des negres qui viue [nt] tres mal, nous auons offert a luy payer pension pour subsister par le moyen de ses prouisions. Il nous a respondu qu'il ne le pounoit faire, a cause qu'estant arriué au Senega [sic], il feroit tout son possible pour partir au plustost aller aux Isles de l'Amerique, ou il ne pounoit nous mener sans vn ordre expres de la Compagnie de sorte qu'il faut se resoudre d'aller aux isles si nous voulons faire le voyage du Cap-Vert veu mesme que nous ne scaurions reuenir en France que dans le mesme Vaisseau.' Captain Layolle was wrong: the envoys did not sail west from Goree on the same vessel.

47 Deshayes to Cassini, Dieppe, 23 December 1681. Bib. Obs. B. 4. 9 bis, bundle 'Deshayes': ' $M r$ de Layolle nous a bien receu et nous a dit qu'il n'auroit pu rien faire sans les lettres que vous nous auez fait la grace de nous faire anoir. Il a veu aussy celle de Mr Jarmineau [sic]'.

48 Deshayes to Cassini, Dieppe, 23 December 1681, Bib. Obs. B. 4. 9 bis, bundle 'Deshayes'. 
wind and tide to allow it to leave the harbour, so the waiting continued. During this period the company proffered a further objection: owing to increased raids by Barbary corsairs, it was claimed that visiting the Canaries might be too dangerous. ${ }^{49}$ It may be that the company hoped the fear of pirates would definitively put the astronomers off. Cassini improvised a response. In January 1682 he informed the Académie of a new plan: the idea of surveying Hierro was abandoned, as it had been ten years earlier in Richer's case, and the envoys were to carry out the 'general' observations in Senegal before heading on to São Tomé.$^{50}$ One result was that the geographers of Europe had to continue waiting for a figure for the longitude of Hierro. ${ }^{51}$

The translation of interests which appeared to have been cemented in Paris to allow the Académie to use Senegal Company ships, a process involving Louis XIV, Colbert, Cassini, Dancourt and the French ambassadors in Madrid and Lisbon, proved almost impossible to replicate at the harbour-side in Normandy. Furthermore, the astronomers' dependence on the company is underlined by the fact that what had been planned as a trip to the Canaries became a triangular voyage to Gorée and the Antilles. Once the Canaries were ruled out for fear of North African corsairs, Cassini had no choice but to make do with the new circumstances and to improvise new 'particular' instructions.

\section{Timekeeping, tobacco and trust}

As if the trouble with the Senegal Company were not enough, Cassini's envoys faced further problems: the travelling itself caused difficulties for their instruments and for their working relationship. Cassini had gone to some trouble to ensure that good observational discipline could be maintained once the envoys had left. It required careful teamwork to produce mean solar time using the sun, two pendulum clocks and a telescopic quadrant. Mean solar time is, after all, an artificial metrological convention - there is no natural reference point - and like other metrological standards, it is epistemologically 'boot-strapped'. It would take over twenty-four hours to know the 'going' of the clocks (their rate relative to solar time), which then had to be monitored with a strict maintenance routine. If the two envoys failed to agree on the 'going' of the clocks, the value of the rest of their work could be undermined. Cassini was equally aware of how much room there was for observational error in tasks as delicate

49 François de Paris explains that 'mesme nous avions désia eu ordre de la Compagnie de mener ces Mrs à Ténériffe. Mais la guerre qui survint avec les Algériens détourna ce voyage, pour le grand danger qu'il y a autour des Canaries'. Thilmans, op. cit. (45), 6. No further mention of the two 'astrologues' is made.

50 AAS, RPV, 9 bis, f. 148r, 17 January 1682: 'Mrs Varin et Deshayes ne pounant aller aux Canaries a cause des Corsaires, iront au Cap Verd en Afrique ou ils feront les obseruations pour la longitude, et la latitude, et $y$ attendront $\mathrm{Mr}$ De Glos qui les y doit joindre pour aller tous ensemble obseruer dans l'isle St Thomé sous la ligne Equinoctiale suiuant les memoires qu'on leur a donné'. Cf. f. 169v (summary of July 1682). In 1672 Richer had tried to pay to stop at the Canaries, but the captain wanted to press on to Senegal. Richer to Cassini, 4 May 1672, Bib. Obs. B. 4. 11 bis, bundle 'Richer'.

51 Lagarde, op. cit. (10): the minim friar Louis Feuillée visited Hierro in 1724, but his results were questioned; Le Monnier visited in 1742; a more durable result was not obtained until 1789. 
as noting the time of the immersions and emersions of Jupiter's satellites. This was a problem endemic to astronomy: two people might well 'see' the same event at different times. This problem (later known as the 'personal equation') was familiar enough to seventeenth-century astronomers, who were aware of the difficulties in drawing the line between phenomenon and illusion..$^{52}$

For many long months Varin and Deshayes were living and working with their instruments and with each other, locked into a routine of mutual checking. Both timekeeping and personal issues were to cause problems for Varin and Deshayes, and both were exacerbated by the voyage itself. Trouble with the instruments could not always be distinguished from interpersonal tensions.

Instrument worries began almost as soon as they set off. Even when still in Rouen, in October 1681, Deshayes reported that the smaller of their two clocks was not running well and he wanted to take it apart and clean it. He planned to ask the clockmakers of Dieppe to look at it. ${ }^{53}$ In mid-November they found that when they came to use the quadrant, the crosswires that should have been fitted within its telescopic sight were missing, and Deshayes gave Cassini a detailed report of his own makeshift attempts to repair the instrument and to readjust it, 'after $M$. V[arin] had left the telescope'. ${ }^{54}$ Interpersonal tensions also surfaced quite early. In their letters to Cassini both Varin and Deshayes each expressed their distrust of the other partner. In December 1681, while they were still in Dieppe, Deshayes told Cassini that he had begun to draw up a table of figures, which he found to be 'not in agreement with certain calculations of M. V[arin]' ${ }^{55}$ At the same time Varin seems to have believed, for some reason, that he was about to be made a member of the Académie (perhaps as an élève): he made a point of not telling Deshayes. ${ }^{\mathbf{5 6}}$

These were only the first small signs of the problems to come. On the night before Le Conquis finally left Dieppe, three months after they had arrived in the town, Deshayes wrote a long letter to Cassini describing his first major disagreement with Varin. Perhaps bored by the waiting, Deshayes had decided to train himself for life aboard ship by trying some of the sailors' tobacco (pétun). The sailors, he noted, swore by it, and Deshayes told Cassini that he 'wanted to try it, to make sure I did

52 See A. Van Helden, 'Telescopes and authority from Galileo to Cassini', Osiris (1994), 2nd series, 9 , 9-29; for nineteenth-century attempts to address such issues see S. Schaffer, 'Astronomers mark time: discipline and the personal equation', Science in Context (1988), 2, 115-45.

53 Deshayes to Cassini, Rouen, 23 October 1681, Bib. Obs. B. 4. 9 bis, bundle 'Deshayes'. In the rest of this section, it should be borne in mind that the letters of Deshayes are much fuller than those of Varin, so the account may well be one-sided.

54 Deshayes to Cassini, Dieppe, 18 November 1681, BN ms n. a. fr. 6197, ff. 87-8 ('apres ... que Mr V. eut quitté la lunette').

55 Deshayes to Cassini, Dieppe, 10 December 1681, Bib. Obs. B. 4 . 9 bis, bundle 'Deshayes' (' $j$ 'avois commencé vne table, je ne l'ay pas trouné conforme a quelques calculs de M. V.').

56 Varin to Cassini, Dieppe, 11 December 1681, BN ms n. a. fr. 6197, ff. 170-1: ‘ Je crois que Mr Des Hayes $y$ peut prendre part puis que les raisons que Vous alleguez de ma reception dans lAcademie luy peunent conuenir comme a moy. Je ne luy en ay pourtant point encore parlé estant bien aise de ne rien faire sur cela ny sur autre chose que par Vostre aduis.' 
not find so many things strange all at once when I embark' ${ }^{57}$ When Varin saw Deshayes smoking he fell into a rage, which led to an argument. Deshayes summarized:

If I told him what I think, I'd tell him that his greatest problem, which makes him unbearable to be with, is the regret that he has [to be leaving] his dear little wife and his family and that he really would like to find some way out of having to leave. He sometimes says, 'for a bachelor, maybe, but for a man with a family to make such a long voyage.. $.58^{58}$

The argument was clearly about more than tobacco. In a port town, on the night before they set sail, Deshayes's smoking experiment triggered off a series of anxieties over the relative authority of Varin and Deshayes, linked to their age and marital status, and over their willingness to accept their now unexpectedly lengthy Atlantic voyage. ${ }^{59} \mathrm{How}$ the argument concluded Deshayes does not report, nor do we have any record of what Cassini thought of it. Nonetheless, the tension between the two envoys remained.

The morning after the tobacco incident, 7 February 1682, Le Conquis finally managed to get out of Dieppe harbour to begin its journey to Gorée. It arrived there on 23 March and two days later Varin and Deshayes came ashore and began to set up their instruments within the French habitation. What happened during the four and a half months that Varin and Deshayes were working on Goree (23 March to 14 July 1682) can be reconstructed from the reports they wrote when they got back. ${ }^{60}$ As before, there were problems with instrument maintenance. Deshayes continued his improvisatory approach. The heavy dew of the Goree night seemed to affect the plumb line on the quadrant, for example. They found that the threads in the quadrant's sights were broken (for the fourth time) and attributed the damage to the presence of an ants' nest inside the telescope's tube. They also found that it was impossible to take readings for magnetic variation on the island because of the enormous quantity stored there of iron bars, one of the commodities the French used to buy slaves from African traders. ${ }^{61}$

As well as these setbacks with the instruments there was the return of the 'personal equation'. Deshayes narrates that on the evening of $16 \mathrm{May}$, as they were watching for

57 Deshayes to Cassini, Dieppe, 6 February 1682, Bib. Obs. B. 4.9 bis, bundle 'Deshayes' ('j'en ay voulu essaier pour ne trouver pas tout a la fois tant de choses etranges quand je m'embarqueray').

58 Deshayes to Cassini, Dieppe, 6 February 1682, Bib. Obs. B. 4.9 bis, bundle 'Deshayes': 'Si je luy disois ce que je pense je luy dirois que son plus grand mal et qui luy rend tout insupportable est le regret qu'il a de sa chere petite femme et de son menage et qu'il voudroit bien trouuer quelque faux fuyant pour le dispenser de s'embarquer. Il dit quelque fois vn garcon encore passe mais vn homme qui a famille faire vn si grand voyage'.

59 Varin's fears echo commonplaces of seafaring literature; compare, for example, J. Atkins, A Voyage to Guinea, Brasil, and the West-Indies; in his Majesty's ships, the Swallow and the Weymouth, London, 1735 : 'A Sea-Life absolutely considered, had so much of Hardship and Danger, that in King John's Time a national Synod ordained, no married Persons should go beyond Sea without publishing their mutual Consent.'

60 The main sources are in Bib. Obs. B. 5. 2, 5-97 (the 'Livre d'Observations', apparently written by Varin on 5-61, thereafter by Deshayes), and 593-4 ('Relation des Observations de MM. Varin, Deshayes et de Glos', which is copied at AAS, RPV, 9 bis, ff. 181r-182v); both need to be read alongside 'Discussion entre Varin et Deshayes', Bib. Obs. B. 4. 9 bis, bundle 'Deshayes', where Deshayes refutes some of Varin's statements.

61 Bib. Obs. B. 5. 2, 78: 'on a trouné vne fourmilliere dans le tuyau et vn pertuis a quoy on a remedié'; 92: ' il ne faut point s'arrester a ce que montre la boussole dans la forteresse y ayant plusieurs magasins pleins de barres de fer'. 
the re-emergence of the first satellite of Jupiter, Varin got up to go to the clock a whole three or four minutes before Deshayes had seen anything.

I asked him if he had seen the satellite, he said yes, and I said I couldn't see it at all. Upon which he went back to his telescope and admitted that he couldn't see anything yet, and, waiting attentively, we eventually saw the satellite, both of us at the same time. So much so, that this must be one of the most certain observations. However, M. Varin has changed his mind about how good this observation is[:] first by comparing it to his previous ones, he thought it must be late by a minute, and thought he might well have made a mistake with the minutes of the quadrant, which I don't doubt. And M. Varin then took off a minute from what he had previously written down. Since then he has changed his mind, in sending from Guadeloupe his Goree observations. It is up to M. Cassini to decide this. ${ }^{62}$

Crucially, the disagreement is referred back to Cassini, which is what Cassini would have told them to do in cases like this.

Some observational problems, though, involved both instrument trouble and interpersonal discipline at the same time. This was the case with a serious disagreement on timekeeping. On the night of 5 April Deshayes and Varin could not agree on a daily adjustment of the clock. Deshayes moved the petit poids (the adjustable weight or poids curseur in the middle of the pendulum rod on a Huygens-style clock) down; Varin moved it back up again. Deshayes thought Varin was doing this just to be contrary, and said the dispute distracted him from his work for several days. ${ }^{63}$ Deshayes persisted in trying to convince Varin, and eventually thought he had succeeded. On 17 April, however, something strange happened around lunchtime:

[Varin] left lunch right at the start, and went alone into our room. I ate quickly to go and see why, against his custom, he had left dinner in this way so soon, fearful of what I would find. Namely the clock completely changed and the hands out of place. I could not stop myself from declaring my suspicion, upon which we had a very fierce quarrel, and I would never have believed that he could hatch such a claim that it was not him and that it must have been me instead. It can only have been him or me, I know that it was not me and I swear it, but it is a secret between the two of us, and there is no way of proving it except according to the credit that people will give to the two of us. ${ }^{64}$

62 Bib. Obs. B. 5. 2, 68-9: 'Je luy demanday s'il anoit veu le satellite il dit qu' ouy et je dis que je ne le voiois point $d u$ tout. Sur quoy il reuint a sa lunette et auoü qu'il ne voioit rien encore et attendant toujours attentiuement, a la fin nous vismes le satellite tous deux en mesme temps. Si bien que cette obseruation deuroit estre encore une des plus certaines. Cependant Mr Varin a esté variable sur l'estime de cette obseruation, d'abord en la comparant a ses precedentes il la crut tardive d'une minute et crut qu'il pounoit bien s'estre trompé aux minutes du quadrant, comme je n'en fais aussy point de doute. Et M. Varin rabattit pour lors une minute de ce qu'il auoit premierement marqué. Depuis il a changé d'auis en enuoyant de la Guadeloupe ses obseruations de Goree. C'est a Monsr Cassini d'en faire la discution.' Another version of Deshayes's account, with slight variations, is at B. 5.9 (unpaginated, sheets headed 'Emersions du premier satelite de Jupiter 1682'): Deshayes here comments, 'Au pis-aller, ce petit different qui est toujours trop grand pour l'exactitude de l'Observatoire n'est rien en comparaison de quelques tables qui font le Cap Vert plus occidental que nous ne le trounons de pres de cinq degrez.'

63 'Discussion entre Varin et Deshayes', Bib. Obs. B. 4. 9 bis, bundle 'Deshayes': 'je fus ebranlé et interrompu par la grande opposition que M. V. me temoigna pour ce que j'anois fait le 5 auril'. Such adjustments were made almost daily.

64 'Discussion entre Varin et Deshayes', Bib. Obs. B. 4.9 bis, bundle 'Deshayes': 'il quitta le disner des le commencement pour venir seul dans nostre chambre. Je disnay viste pour venir bientost voir pourquoy contre sa coustume il auoit ainsy quitté le disner me doutant presque de ce j'allois trouner. Scauoir l'horloge toute 
As always, Deshayes's letters are useful in the extent to which they reveal the instability of observational practice. We can see how the personal tensions that had first flared up in the tobacco incident could re-emerge in debates on procedure, as soon as personal authority was at issue. If the two observers stubbornly failed to agree, it could only be a matter of one testimony against the other, so a difficulty over timekeeping became a contest of personal credit (créance). When Varin came to write up his account, Deshayes felt it necessary to justify himself, and countered Varin with his own version of events. From this point on they kept separate figures for the correction of the clock. ${ }^{65}$

\section{After Gorée}

It proved impossible to get a passage from Gorée to São Tomé, so the three astronomers crossed the Atlantic, not aboard Le Conquis, but on La Sirène (The Siren), another 'prize' ship, recently taken from the duchy of Courland's slave-trading company, which left Gorée on 14 July 1682 with a cargo of 250 slaves and arrived at Guadeloupe in late August. The astronomers stayed several months in the Antilles, but Varin appears to have split off from Deshayes and de Glos, because he seems not to have been with them when they visited Martinique in November. ${ }^{66}$ Varin was back in Paris first, by February 1683. As far as can be known, the row between Varin and Deshayes was never resolved, except in a de facto sense, when Cassini compiled the report of the mission for publication. In the printed report, in accordance with the conventions governing the Académie's publications, all of the disagreements were passed over in silence. ${ }^{67}$ One of their results was met with doubt: they had found that the seconds pendulum indeed did require shortening at Gorée, by as much as two-twelfths of a Paris inch, even more than Richer had found in Cayenne. The doubt was probably due to the timekeeping uncertainties. As a result the Académie was unsure whether this confirmed Richer's finding or not. ${ }^{68}$ Further pendulum measurements at latitudes close to the equator were therefore required.

Both Varin and Deshayes continued to work for the Académie, while remaining officially outside it. They were briefly employed in surveying the Paris meridian, after which Varin was given a post as a hydrography teacher at Rochefort which he held until

changée et les aiguilles hors de leurs places. Je ne pus m'empescher de luy declarer mon soupçon sur quoy nous eumes vne tres forte querelle et je n'eusse jamais creu luy tramer vne telle assurance a soustenir que ce n'estoit point luy et qu'il faloit plutost que ce fust moy. Ce ne peut estre que luy ou moy je scay bien que ce n'est pas moy et j'en jure mais cet vn secret entre nous deux et il n'y a point de preuue que suiuant la creance qu'on donnera a l'un et a l'autre'.

65 See Varin's report ('Livre d'Observations', B. 5. 2, 5-65, esp. 13), and Deshayes's response in 'Discussion entre Varin et Deshayes' (Bib. Obs. B. 4. 9 bis, bundle 'Deshayes').

66 This information comes from comparing Thilmans, op. cit. (45), with Bib. Obs. B. 5. 2, and with the printed 'Observations astronomiques faites au Cap Verd', op. cit. (5) (where the date given for the landing at Guadeloupe in October is a misprint).

67 This was in accordance with the Académie's publishing policies. See C. Licoppe, La Formation de la pratique scientifique: le discours de l'expérience en France et en Angleterre (1630-1820), Paris, 1996, 53-87.

68 Several measurements were made at Goree, and the length recorded by cutting a piece of straw (Bib. Obs. B. 5. 2, 18, 28, 55, 79-84). On the envoys' return, the Académie ordered repeat measurements to be made (AAS, RPV, 9 bis, f. 192v., Saturday 6 March 1683). 
his death in 1697. Deshayes published surveying manuals and continued to travel, circling the Atlantic again in 1685-6 and 1699-1700. In 1702 he moved to Canada as royal hydrographer of New France, and produced a fine chart of the St Lawrence estuary. He stayed in Québec until his death in $1706 .{ }^{69}$ What happened to Guillaume de Glos is not known.

Long-range scientific travellers in this period were of necessity forced into a circuit of ships, commodities, sailors and slaves. Numerous borders, cultural as much as physical, were crossed, with implications for the reliability of the envoys and of their instruments. In the seventeenth century, replicating experiments while maintaining trust was difficult enough even within Europe. When the distances involved became intercontinental, the problem of maintaining authority became especially acute. Although increasingly bound up with the period's rising tide of new information, trade clearly caused trouble for the certitude of scientific knowledge. ${ }^{70}$ In following Varin, Deshayes and de Glos around their triangular voyage, we have revealed two sets of difficulties: first, the problem of discipline and authority that existed at the level of instruments and their use, such as maintaining timekeeping and distinguishing signal from noise; and second, the problems that beset the Académie's attempt to set up and maintain a functioning network of communication within the already existing trade networks. Both are crucial to the understanding of the emergence of what was to become one of the characteristic forms of scientific life in the eighteenth century - the long-range expedition.

We have seen how in the late seventeenth century the Académie des sciences was unable to send out 'expeditions' on its own, but was dependent for the transport of its envoys upon other organizations, in this case the newly refounded Compagnie du Sénégal, which dictated the destinations visited. In this respect, the experience of the Académie mirrors that of the French metropolitan authorities, who, as Kenneth Banks shows, were just as dependent upon the networks of merchants, even in the middle of the eighteenth century. ${ }^{71}$ This account, then, can serve to remind us that the 'colonial

69 For the meridian work see Comptes des Bâtiments $d u$ Roi, op. cit. (35), ii, col. 236; for Varin's fate see Archives nationales, Marine $\mathrm{B}^{2}$ 130, f. 49; J. Deshayes, L'Usage du compas de proportion de D. Henrion, Paris, 1681; reprinted 1685; idem, La Théorie et la pratique du nivellement, Paris, 1685; reprinted 1695. Deshayes's 1699 voyage is recorded in Bib. Obs. B. 5. 2, 325-56. For Deshayes's later work as surveyor in Canada see P.-G. Roy, 'Jean Deshayes, hydrographe du roi', Bulletin des recherches historiques (1916), 22, 129-33; J. S. Pritchard, 'French developments in hydrography with particular reference to the St Lawrence River during the reign of Louis XIV (1665-1709)', University of Western Ontario MA thesis, no. AAT EC45619, 1965; idem, 'Early French hydrographic surveys in the Saint Lawrence river', International Hydrographic Review (1979), 56, 133-52; Regourd, op. cit. (4), 291-4; and M. Schotte, 'A hydrographer's library: Jean Deshayes and navigational education in early eighteenth-century Quebec', University of Toronto, MA thesis, 2007.

70 See, for comparable points on travel and science, N. Safier, 'Fruitless botany: Joseph de Jussieu's South American odyssey', in Delbourgo and Dew, op. cit. (1), 203-24; Schiebinger, op. cit. (1), 65-72; Dew, 'Vers la ligne', op. cit. (24), 58-60; and the essays in M.-N. Bourguet, C. Licoppe and H. O. Sibum, eds., Instruments, Travel and Science: Itineraries of Precision from the Seventeenth to the Twentieth Century, London, 2002. For wider contexts see Harris, op. cit. (1); and S. Shapin, A Social History of Truth: Civility and Science in Seventeenth-Century England, Chicago, 1994, 243-309.

71 Banks, op. cit. (6), 153-83. Although Banks's evidence is from the period 1713-63, his conclusions seem likely to apply to the 1680 s. 
machine' did not always run smoothly. As J. B. Shank notes, a long tradition in the historiography of modern French science gives a special explanatory role to the state. What seem to be distinctive features of French scientific practice often tend to be explained by reference to Bourbon bureaucracy. Among other uses, tracing the movements of colonial actors can remind us that 'the state', rather than being a prior structure, was as much being made by such movements as were 'society', 'science', 'commerce' or 'colonialism'. In this respect, unpacking expedition narratives not only can contribute to our image of how long-range science was performed, but might also help us revise the sense of some of our most often used 'macro' concepts. ${ }^{72}$

72 See the remarks in J. B. Shank, 'The sciences in Old Regime France: a review of recent scholarship', French Historical Studies (2005), 28, 661-95, esp. 668-71. 